\title{
Bir Dijital Pazarlama Stratejisi Olarak Etkileşimli Reklamların Etkinliği: Deneysel Bir Çalışma
}

\author{
DOI: 10.26466/opus.583849 \\ * \\ Makbule Büşra Çetinkaya* - Rukiye Çelik** \\ * Dok. Öğrencisi, S D Ü , İletişim Fak., Halkla İlişkiler ve Tanıtım Bölümü/ Isparta / Türkiye \\ E-Posta: busraeyiis@gmail.com ORCID: $0000-0003-3294-6426$ \\ ** Dr. Öğr. Üy., S. D.Ü., İletişim Fakültesi, Halkla İlişkiler ve Tanıtım Bölümü / Isparta/ Türkiye \\ E-Posta: bursa-84@hotmail.com \\ ORCID: $\underline{0000-0002-2538-0228}$
}

\section{Öz}

Günümüzde enformasyon ve haberleşmenin yanı sıra kişiler arası etkileşimi sağlayan pazarlama stratejileri de teknolojiden önemli bir pay almıştır. Bu çalışmada dijital pazarlama stratejisi olarak etkileşimli reklamın etkinliği araştırılmıştır. Bu çerçevede deney olarak tasarlanan çalışmada etkileşimli, pre-roll ve skip pre-roll reklamların etkinlik düzeyleri ölçülerek kıyaslanmıştır. Deney için bir kamu üniversitesinde eğitim görmekte olan ve kolayda örnekleme yöntemi ile belirlenen 90 öğrenciye ulaşılmıştır. Deney öncesinde anket uygulanan öğrenciler ü̧̈ gruba ayrılmış ve her bir gruba farklı reklam türü hazırlanmıştır. 30'ar kişilik deney, kontol 1 ve kontrol 2 gruplarına 7 gün boyunca gruplart için seçilen 20'şer reklam izletilmiş ve deneyin ardından tekrar anket uygulanmıştır. Ön test ve son test sonuçları arasındaki farklar analiz edilmiştir Çalışmanın sonuçlarına göre; kullanıcıların duygusal ve bilişsel ilgileniminin, markaya yönelik tutum ve satın alma niyetinin en çok artış gösterdiği reklam türü etkileşimli reklam olarak bulunmuştur. Bu sonuçtan hareketle dijital pazarlama stratejisi olarak etkileşimli reklamin diğer reklam türlerine göre daha etkili olacağı söylenebilir.

Anahtar Kelimeler: Dijital pazarlama, Etkileşimli reklam, Deneysel çalışma 


\title{
Effectiveness of Interactive Advertising As A Digital Marketing Strategy: An Experimental Study
}

\begin{abstract}
Today, in addition to information and communication, marketing strategies that provide interpersonal interaction have taken an important role in technology. In this study, the effectiveness of interactive advertising as a digital marketing strategy was investigated. In this study, the effectiveness levels of interactive, pre-roll and skip pre-roll ads were measured and compared. For the experiment, 90 students educated at a public university and easily determined by sampling method were reached. Before the experiment, students were divided into three groups and different types of advertising were prepared for each group. 30-person experiment, Control 1 and Control 2 groups were selected. 20 selected ads were tracked for groups for 7 days and then the survey was applied again. Differences between pre-test and post-test results were analyzed. According to the results of the study, the type of advertising, in which the user's emotional and cognitive interest, attitude towards the brand and purchasing intentions increased the most, was found to be interactive advertisement. Based on this result, it can be said that interactive advertising as a digital marketing strategy will be more effective than other types of advertising.
\end{abstract}

Keywords: Digital marketing, Interactive advertising, Experimental study 


\section{Giriş}

Yakın geçmişe kadar gazete, radyo ve televizyon ile kısıtlı olan kitle iletişim araçları günümüzde teknolojinin hızla gelişmesiyle önemli bir aşama kaydetmiştir. Toplumsal gelişim sürecinin bir göstergesi olan teknoloji; dijitalleşmeyle birlikte, birbirinden farklı alanların değişim içinde olmasinı zorunlu kılmıştır (Yengin, 2012, s.123).

Günümüz kitle iletişim araçlarından; telefon, bilgisayar ve internet yaşamımızın her alanında vazgeçilmez bir konumda yer alır. İnternet erişiminin herkes tarafından sağlanabiliyor olması ile yeni medyanın etki alanı genişlemiş̧ir. Tek taraflı iletişim, dijitalleşen yeni medya ile birlikte geri iletinin sağlanabildiği karşılıklı etkileşim içeren iletişim modeline evrilmiştir. Etkileşimli medya, kullanıcının aktif olduğu çift yönlü bir iletişim biçimi sağlayarak günümüzde birçok dijital alanda kullanılmakta olup özellikle reklam sektöründe ön plana çımaya başlamıştır.

İçinde bulunduğumuz dönemde internet kişiler için vazgeçilmez bir iletişim aracı haline gelmiştir. İnternet aracılığıyla bulunduğumuz herhangi bir ortamda enformasyona ulaşmak oldukça kolay bir hal almıştır. Kişisel veya toplumsal gündelik bilgiye ulaşmak istediğimizde, ulusal veya uluslararası gündem hakkında bilgi sahibi olmamızda, kişisel paylaşım veya araştırma yapacağımızda ilk başvurduğumuz kaynak görevini çoğu zaman üstlenmektedir. İnternet kullanımı için mekân ve zaman k1sıtlaması olmaması, internet üzerinden aynı zamanda geleneksel iletişim mecraları olan gazete, dergi ve televizyona da erişilebilmesi internetin hayatımızın önemli bir bölümü haline gelmesinin açık sebeplerindendir.

Geleneksel medya için kolayca erişim sağlanan bu iletişim ortamı geleneksel reklamların da kullanıcıya ulaşmasında önemli bir araç haline gelmiştir. Gelişen teknoloji ile sürekli kendini yenileyen internet de geleneksel reklamı farklı bir biçime dönüştürmüştür ve bu şekilde etkileşimli reklamlar gelişmiştir. Dijital reklamlar; internet, telefon, bilgisayar vb. ile kullanıcıya ulaşır ve bunun sonucunda kullanıcı ile reklam arasında etkileşimi gerçekleştirirler. İnternet aracılığı ile sağlanan çift yönlü iletişimde eş zamanlılık ile etkileşim gerçekleşir ve bunun sonucunda kullanıcı reklama karşı iletişime açı hale gelir (Gün, 1999, s.47). Günümüzde bilgisayar ve akıllı telefon kullanımının yaygın hale gelmesi de internet reklam- 
larının sıklığını ve reklam veren kurum ya da kuruluşlar tarafından sıklıkla tercih edilmesini sağlamıştır. İnternet reklamcılığı geleneksel reklam uygulamalarının gelişmiş bir biçimi olarak kullanılmaktadır. İnternetin reklam mecraları içerisinde yeni bir uygulama olarak görülememesi geleneksel reklam mecralarının çok ötesine geçemediğini ve teknoloji ile faklı yöntemler izlemesi dişında önemli farklılıklar taşımadığı düşünülmektedir. İnternet ortamında uygulanan reklamların kullanıcının dikkatini çekmesi ve hakkında bilgi edinme isteği ile işleyen bir süreç olmasından kullanıcı kontrolüne bağlı bir reklam biçimidir. İnternet reklamlarının zamanla geleneksel bir reklam uygulamasına dönüşmesi Cappo'e (2005, s.195) göre, internet ağının çok yönlülüğü onu diğer mecralardan farklı ve üstün kılar bununla beraber geleneksel medyadan belli olguları da kapsayarak ilerlemesi ile bir entegrasyon sağlar.

Geleneksel medya için kolayca erişim sağlanan bu iletişim ortamı geleneksel reklamların da kullanıcıya ulaşmasında önemli bir araç haline gelmiştir. Gelişen teknoloji ile sürekli kendini yenileyen internet de geleneksel reklamı farklı bir biçime dönüştürmüştür ve bu şekilde etkileşimli reklamlar gelişmiştir. Dijital reklamlar; internet, telefon, bilgisayar vb. ile kullanıcıya ulaşır ve bunun sonucunda kullanıcı ile reklam arasında etkileşimi gerçekleştirirler. İnternet aracılığı ile sağlanan çift yönlü iletişimde eş zamanlılık ile etkileşim gerçekleşir ve bunun sonucunda kullanıcı reklama karşı iletişime açık hale gelir (Gün, 1999, s.47).

\section{Dijital Reklam Ve Dijital Pazarlama}

İlk kez 1994 yılında hotwired.com'da karşılaştığımız banner reklamları, birçok farklı kaynakta internet reklamcılı̆̆ının ilk örneği olarak karşımıza çıkmaktadır (Aktaş, 2010, s.151). 1994 Ekim ayında yayınlanan banner reklamı, AT\&T web sitesine bağlantı vererek ilk kez ticari bir amaçla kullanılan reklam olma özelliğini kazanmıştır (Çelik, 2016, s.24). İlk örneğinin ardından Maytag, United Airlenes gibi büyük şirketlerde banner reklamlar sıkça görülmeye başlamış ve günümüze kadar varlığını sürdürmüştür. Başlangıçta yalnızca başka bir web sitesine yönlendirme olarak ortaya çıkan banner reklamlar, günümüzde kullanıcılara; video içeriği izleme, dosya indirme, arama yapma, mesaj gönderme, navigasyon ile yönlen- 
dirme, anket doldurma veya satın alma gibi birçok işlemi yapmada kolaylık sağlıyor (Varnalı, 2013, s.71). İlk internet reklam türü olarak karşımıza çıkan banner reklamların yanı sıra günümüzde birçok farklı tür ve formatlarda reklamlar, internet reklamcilı̆̆ kapsamında görülmektedir. Bu bağlamda banner reklamları da içine dahil eden Display reklamlar, e-posta reklamları, arama motoru reklamları, sosyal medya reklamları, web sitesi reklamları, viral reklamlar ve daha birçok farklı reklam türü günümüzde aktif olarak kullanılmakta ve bunlara her geçen gün bir yenisi eklenmektedir. İnternetin hızlı gelişimi ve kitlelerin dijital cihazları kullanım alışkanlıklarıyla doğrudan ilişkili olarak gelişen dijital reklamcılığın birçok tanımının bulunması ile beraber, daima gelişen ve değişen bir mecra olması da reklam türlerinin ve tanımlarının sürekli değişmesini beraberinde getirmektedir.

Dijital reklamcılığının güncel tanımlarını incelediğimizde Önal ve Bendaş, (2017, s.113) bir ürün ya da malın kişilere doğrudan internet aracılığ ile tanıtılması olarak dijital reklamı genel bir çerçevede tanımlamıştır. Çelik (2016, s.23), dijital reklamin, internet vasıtasıyla bilgisayar ve cep telefonu kullanıcısına ulaştığını ve bu reklamların arama motoru reklamı, banner reklamlar, video, e-posta reklamları, sosyal medya reklamlarından oluştuğunu belirtmektedir. Peltekoğlu (2016, s.67) ise; internetin, pazarlama stratejileri için önemli bir kavram olduğunu, hem yerel hem de küresel bir markanın günümüze uyum sağlayabilmesi, ekonomik devinime tutunabilmesi ve markasına en uygun tüketiciye ulaştırabilmesi için web sitelerinden yararlanmaları gerektiğini belirtmektedir. Kırcova (2008, s.211) ise; internet reklamların, internet ortamında yer alan sayısız web sitesi içeriği olarak karşımıza çıkan, birçok ticari içeriğin kullanıcıya duyurularak tanıtılması için kullanılan bir reklam aracı olarak internet reklamcılığını tanımlamaktadır. Business Sözlüğü'nün (2018), dijital pazarlama tanımı ise; dijital ortamda farklı tür ve şekillerle bir ürün, mal veya markanın tanitılmasıdır (www.businessdictionary.com). Dijital reklamın, geleneksel pazarlama yöntemlerinden ayrıldığ 1 nokta, hedef kitleye ulaşmakta kullanılan kanallardır. Bunun yanı sıra yeni medya ile yaşamımıza giren cep telefonu, bilgisayar, internet gibi kavramlar ile dijital pazarlama bu derece önem kazanabilmiştir. Dijital reklam, tüketici ile güçlü bir etkileşim kurmayı amaçlarken aynı zamanda ölçülebilir veriler elde etmeyi hedefler. Bu bağlamda Penpece (2013, s.52) dijital pazarlamada; doğru 
hedef kitleye ulaşarak kullanıcı grubuyla etkileşimli bir ilişki kurmak ve rasyonel sonuçlara ulaşmanın önemini belirtmiştir. Aynı zamanda sosyal ağlar yoluyla tüketiciye ulaşarak iletişim kurmak, var olan müşterinin memnuniyet düzeyini artırarak satış oranını artırmak ve markaya bağlamak, tüketici ile güven bağı kurmak gibi amaçları gerçekleştirir. Bu kavramlar reklamcılık ve pazarlama açısından büyük önem taşımakta olduğundan işletmelerin sosyal medya ve gelişen teknolojiyi kullanması kaç1nılmazdır. Teknolojinin gelişimine ayak uyduran ve bu bağlamda çalışmalar yaparak yeni stratejiler geliştiren işletmeler daha hızlı büyüyerek bunu önemli bir avantaj olarak kullanmaktadır (Alan, 2018, s.497).

İnternet aracılığı ile ortaya çıkan e-ticaret kavramı 1997 yılında kullanılmaya başlanmış ve ortaya çıkışından günümüze kadar pazarlama için önemli bir yer edinmiştir. Dijital pazarlama, OECD'ye üye olan ülkeler arasında ekonomik gelişmelerin yaşanacağının habercisi olmuştur (İnce, 1999). Dijital pazarlama ya da diğer adıyla elektronik ticaretin birçok tanımı mevcuttur.

En genel anlamda, dijital ortamlar yolu ile kullanıcilara bir ürünü tanıtmak veya pazarlamak olan dijital pazarlama ile tüketicilere internet üzerinden ses, metin, video vb. içeriklerin iletilmesi sağlanır (Özmen, 2013, s.365). Dijital pazarlama Dijital pazarlamada: SEO- SEM- web site, sosyal medya, video, banner, display, e-posta reklamları gibi çeşitli reklam türleri kullanılarak bir ürünün tanıtımı ve satışı hedeflenir. Tüketici bu tanıtım sayesinde ürün ve marka hakkında kampanyaları, ürünün sağlayacağı hizmetleri ve ürün ile ilgili diğer tüm bilgileri edinebilir. Öte yandan teknoloji dönüşürken etrafından kendi devinimine eklediği belli kavramlar olmuştur. Bu kavramlara ürün ve pazarı da dâhil etmemiz yanlış olmaz (Hartman, Sifonis ve Kador, 2002, s.185). elektronik pazarlamada ürün ve pazar dönüşümünün yeni sınırlandırmaları ve yeni tasarımlarını oluşturarak başarının daha fazla artırabileceğini ifade eder. Dijital pazarlamayla kullanıcı ile web sitesi, e-posta, sosyal ağlar, bloglar veya herhangi bir internet ortamı aracılığıyla etkileşim kurulur ancak bu süreçte kullanıcının gizlilik sınırlarına girmeden ve kullanıcı odaklı, onun için tarlanmış, özel bir ürün ya da hizmet sunulur. Öte yandan bu bilgilerin müşteriye sunulurken rahatsız etmeyecek düzeyde faydalı olması amacıyla üretilen; gerekirse kullanıcının internet ortamında bıraktığı izler takibe 
alınarak buna yönelik teklif ve hizmetler sunulmalıdır (Özmen, 2013, s.365).

Dijital pazarlamanın günümüzün en etkili reklam mecralarından biri olmasını Aktaş (2010, s.151), internetin diğer geleneksel kitle iletişim araçlarından farklı olarak, teknolojik olanaklar sunarak içerikleri daha etkili hale getirirken; görsel ve işitsel tüm öğelerden de yararlanabilmesi ve sonucunda tüketiciye daha etkili bir biçimde sunmasına bağlamıştır. Dijital reklamın tüketici üzerinde etkili olabilmesi için yüksek bütçeli bir işletme olmaya gerek yoktur. Köse ve Yengin'e (2018, s.81) göre; dijital reklamın başarılı olması için ihtiyacı olan en önemli olgunun yenilikçi olmaktan geçtiğini, bu özellik sayesinde ilgi çekici ve başarılı olacağını belirtirler.

Dijital reklamı diğer reklam türlerinden ayırıcı ve avantajlı kılan en önemli özellikleri; çift yönlü olması, ucuz ve ulaşılabilir olması, daha hızlı bir şekilde ulaşabilmemiz gibi özelliklerdir (Vural ve Öz, 2007, s.224). Dijital reklamın özellikleri ve avantajları konusunda genel bir tutumla; her yerde bulunabilme (ubiquity), interaktiflik, paylaşım, uzmanlaşma, kişiselleştirme, kendiliğinden yayılım gibi belli temel özellikler sunulmaktadir (Erdem, 2014; Aksoy, 2009).

Erdem'e (2014, s.161) göre; dijital reklamın dört temel özelliği bulunmaktadır. İlki; reklamın her yerde bulunabilirliği, sebebini ise teknolojik cihazların kullanımındaki artış ve insanın gündelik yaşamında önemli bir yerde olmasına bağlamaktadır. İkinci özelliği olan etkileşim ve karşılıkl1lığ 1 ise; web 2.0 teknolojisinin gelişmesi ile sıradan bir internet kullanıcısının da içeriğin üretiminde etkin bir rolü olmasını meydana getirir ve bu süreç de reklam ile tüketici arasında bir etkileşim oluşmasına sebep olur. Üçüncü özelliği olan kişiselleştirme ise, dijital medya içeriğinin tüketiciye özel bir biçimde sunulması anlamına gelir. Kullanıcının dijital medya ortamındaki geçmiş deneyimlerinden ulaşılan bilgiler vasıtasıyla elde edilen bilgilerin kişinin ilgilerine göre en uygun reklamın sunulmasıdır. Son olarak kendiliğinden yayılım diğer anlamıla viral etki özelliği ise; geleneksel pazarlama yöntemlerinden olan ağızdan ağıza pazarlamanın dijital ortama adapte edilmesi ile gerçekleştirilir. Geleneksel ortamda sınırlı sayıda insana ulaşan bu yöntem dijital ortamda bloglar veya kişisel hesaplar sayesinde binlerce kişiye ulaşabilir. Bu özelliklerin yanı sıra Aksoy (2009: 40) ise; paylaşım, uzmanlaşma, sanal değer yaratma, web sitesi kullanımı 
gibi özellikleriyle internetin reklamcılık ve pazarlama bağlamında önemli etkilerinin olduğunu belirtmiştir.

Daldal ve Kılıç, (2014, s.123) dijital reklamın ve mobil pazarlamanın, kullanıcının sahip olduğu teknolojik cihazlara her daim erişimin gerçekleşebilmesinin en önemli özelliği olarak kabul etmektedir. Buna ilaveten; birebir pazar anlayışına sahip olması, ölçülebilir olması, maliyetinin düşük olması, tek veya çift taraflı iletişimin mümkün olması ve hızlı olması gibi özelliklerinin de önemini vurgulamaktadır. Pencepe'de (2013: 108) benzer olarak; dijital ortamın daha samimi, anlaşılır, güncel, tutarlı, tüketicinin içeriğe katkı sağlamasına izin veren, hedef kitleye uygunluk ve harekete geçirme yönlerinden güçlü, değer yaratan ve hayat tarzı oluşturan, farklılık katabilen, eğitici ve duyguyu kullanıcıya hissettirebilme bakımından güçlü bir ortam olduğunu ifade etmektedir.

İnternet reklamları ile doğru sayısal bilgilere ulaşılabilmesi, işletmelerin iyi bir strateji planlamasında önemli bir etkendir. İnternet reklamlarının tüketici üzerindeki etkisini ölçmek için birçok yol vardır. En sık kullanılanı ziyaretçi sayısı ile reklamın görüntülenme sayısıdır. Ulaşılan her iki sayının birbirine yakınlık derecesi reklamın etkinliği ile ilgili önemli bir bilgi verir. Reklamı gören kullanıcının tıklayarak sayfaya ulaşması, doğru kullanıcıya ulaştığının ve etki ettiğinin göstergesidir. Öte yandan sayfada ne kadar süre geçirdiği de etkinliği ölçmek için önemli bir veridir. Bu bilgiler vasıtasıyla işletmeler, kullanıcının reklamı görüp görmediğini, sayfaya kaç kez tıkladığını ve açtığını, sayfada ne kadar süre gezdiğini ve diğer işlemlerini anında görüntüleyebilerek bilgilere ulaşabilir ve stratejilerini bu yönde geliştirebilir (Vural ve Öz, 2007, s.232).

İnternet reklamlarının bu kadar fazla kullanılması, eğlence içerikli olması, web sitesindeki içeriğin daha zengin ve dikkat çekici olması, internetin kolaylıkla ulaşılabilir bir ortam olması gibi sebeplere bağlanabilir (Çakır, 2004, s.171). Zaman veya mekân uyumu gerektirmeyen, 7/24 saat istediğimiz an ulaşabildiğimiz bir platformda yer alıyor olması, görsel, işitsel ve duyusal olarak kullanıcıya hitap etmesi ve dikkatini çekmesi, satış yapmak ve bunu gerçekleştirirken rakiplerinden farklı olabilmek adına daha ucuz ve kaliteli olmayı ön planda tutması, kullanıcı ile bire bir iletişime geçebilmesi, kullanıcıya özel içerik üretebilmesi, uluslararası alışveriş yapabilme seçeneğini sunması, değişen herhangi bir bilgiyi (fiyat vb.) 
anında değiştirerek tüketiciye en güncel bilgiyi anında verebilmesi, firmanın tüketici istekleri doğrultusunda hareket edebilmesi gibi sebeplerle firmalar internet reklamcılığını sıklıkla kullanmaktadır.

Dijital reklamların kullanıcıyı eğlendirerek isteklerini karşılaması her iki taraf içinde önemli bir avantaj iken; kullanıcının ilgisini çekmeyen, ihtiyacı olmayan veya ilgilenmediği bir reklam ile mail, internet sitesi, sosyal medya vb. reklam türü olarak karşılaştığında hoşlanmadığı ve bir an önce reklamdan kurtulmak istediği sonucuna ulaşılmıştır (Tosun, 2004, s.161). Fakat kullanıcının almak istediği veya düşündüğü, ilgilendiği bir alana ait, iş veya gündelik yaşamında kullanabileceği kısaca ona yönelik, kendine özel bir ürünün reklamı ile karşılaştığında eğlenir ve etkilenir. Bu durum günümüz teknolojisiyle Web üzerinde bıraktığımız izlerimiz sayesinde rahatlıkla sağlanır ve bununla kullanıcı; kişiye özel, ilgi alanına yönelik reklam iletileri ile karşılaştırılır. "Dijital iz takibi" ile farklı veri tabanı programları uygulanarak kullanıcının belli bilgilerine ulaşılır (Atabek, 2006, s.3). Bu durum etik olarak tartışılmakta olsa da kullanıcının izniyle gerçekleşen ev adresi bilgileri, sağllk bilgileri, banka bilgileri, web üzerinden arama yaptığımız bilgiler, konum bilgilerimiz ve teknolojiyi kullanırken girdiğimiz çoğu adım "büyük veri" nin bir parçası oluyor. Gerçekleşen iz takibi ile özgür bir iletişim ortamı olarak değerlendirilen; internet, kullanıcıları ekonomik ve sosyal bakımdan bazı noktalarda düşündürmektedir. Aynı zamanda iz, izlenenin izleyen tarafından bir güç unsuru içerdiği anlamına gelmektedir (Kurt, 2018, s.74). Öte yandan devletler, büyük dijital şirketlerin bu verileri elde ettiğini ve büyük bir güce sahip olduğunun farkına vararak kişisel bilgilerin gizliliğgi, "dijital veri gizliliği" gibi yeni yasalar çıkarmaktadır. Fakat devletlerin de ulaşabildiği 'büyük veri' ile toplumsal ve ekonomik problemlerde büyük veriyi analiz ederek önemli bilgilere ulaşıyor ve bu bilgiler doğrultusunda birçok gelişme yaşanıyor. Dijitalleşmenin önemli boyutta hayatımızın içinde olması ile verilerin depolanmaması veya kişisel bilgilerimizin ve tercihlerimizin dijital veri depolarında tutulmaması oldukça zor görünmekte. Gündelik yaşamımızda eğlence, bilgi alma veya hayatımızı kolaylaştırma amacıyla kullandığımız internet vasıtasıyla tüm uygulamalar ve web sayfaları aslında veri toplama için en büyük aracılardır. En sık kullanılan uygulamaları incelediğimizde hepsi bir amaç ve genel paylaşım içeriği sunmaktadır. Bu 
içeriklerden yola çıkarak, nereye daha sık gittiğimiz, hangi müziği dinlediğimiz, fotoğraflarımızdan yola çıkarak arkadaşlarımız, giyim tercihlerimiz ve daha fazla bilgi aslında kendi onayımız doğrultusunda büyük veri şirketleri tarafında toplanır. Bununla beraber karşımıza ilgilendiğimiz bir ürünün reklamı olarak çıkabilir.

\section{Etkileşimli (İnteraktif) Reklamlar}

İnteraktif reklamların kullanıcı odaklı tasarlanıp geliştirilmekte olmasını, dijitalleşmeye paralel olarak ortaya çıkmasıyla ilişkilendirmek yerinde olacaktır. Pazarlama ve iletişim faaliyetlerinin en önemli unsuru olan kullanıcının bu noktada rolü çok büyüktür. Kullanıcının reklama olan tutumu, etkisi, önerileri veya ilgisini yakalayabilmek için teknoloji ile hayatımıza giren, yeni iletişim teknolojilerinden ve alt başlıklarından yararlanmak, reklam ve pazarlama stratejileri geliştirmekte oldukça önemlidir (Özmen, 2013, s.367). Dijitalleşme ile hayatımıza giren etkileşimlilik kavramı, geleneksel reklam mecraları ile dijital reklamları birbirinden farklılaştıran en önemli unsurdur (Yüksektepe ve Haşıŏlu, 2017, s.271). Dijital çağda etkileşim kavramı, birçok alanda olduğu gibi reklam sektöründe de daha başarılı olabilmenin, kullanıcının ilgisini çekerek, hızlı geçişlerin olduğu bu dönemde firmaların ayakta kalabilmesinin en etkin yolu olarak değerlendirilir. Hareketsiz veya kullanıcıyla etkileşim içinde olmayan bir reklam ile hareketli görsel, işitsel imgelerin kullanıldığı etkileşimli bir reklam türü karşılaştırıldığında; etkileşimli reklam türü, tüketicinin daha fazla ilgisini çekerek, firmanın daha kolay bir şekilde adını ve ürününü tanıtmasını sağlarken aynı zamanda hedef kitleyi de daha fazla etkilemektedir (Şahin, 2018, s.27). Yeni medya ile yaşamımıza giren üretici ve tüketiciyi birbirine bağlayan etkileşimlilik faktörü zaman ve mekân kısıtlarını ortadan kaldırarak iletişimin iki yönlü olmasıyla beraber kitle iletişim aygitlarının içerik ve düşünce olarak yeniden şekillenmesine neden olmuştur. Böylece reklamın odaklandığı nokta bir ürünü tanıtmak ve satışını gerçekleştirmekten çıkarak; tüketicinin ihtiyaç ve beklentilerine karşılık verebilecek aynı zamanda onları eğlendirirken, ürün veya marka ile ilgili birçok bilgiye sahip olmalarını ve reklamın içinde yer alarak bir parçası 
olmalarını sağlar (Özkaya, 2010, s.462). Kısaca etkileşimli reklamlar, doğrudan tüketici odaklı bir reklam içeriğinin oluşturulmasını ve bilgi akışının tüketici ile üretici arasında gerçekleşmesini beraberinde getirmiştir.

Etkileşim kavramını açıklayan çift yönlü veri iletiminin, teknolojinin hızlı dönüşümü düşünüldüğünde doğal bir süreç olduğunu söyleyebiliriz. Dijital reklamda etkileşim, en genel tanımıyla, kullanıcının reklama dâhil olmasıdır (Yılmaz, 2017, s.264). Dijital teknolojilerin sunduğu kişiselleştirme ve etkileşim fikri, demografik özelliklerin belirlenip daha hedefe yönelik reklamın ötesinde tüketicinin reklam sürecinin içinde yer aldığı, kişiselleştirilmiş ve reklamın içerisinde tüketicinin de var olduğu bir süreç ile meydana gelir (Güney, 2006, s.81). Varnalı ise (2013, s.59) benzer şekilde; pazarlama ve dijitalleşme sonucunda gerçekleşen en önemli değişimin; ürün- marka ve tüketici ilişkisini daha etkili hale getirerek çift yönlüleştirmesi olduğunu belirtmiştir. Ayrcıca dijitalleşme ile hayatımıza giren etkileşim veya diğer adıyla interaktivite kavramlarının, dijital reklamcllıkta kullanılan en önemli yeniliklerden olduğunu ifade etmiştir (Erdem, 2014, s.163). Geleneksel reklamlarda, tüketiciler kendilerine izletilen, okutulan veya dinletilen ürün seçenekleri arasında bir karar verme süreci yaşarken, günümüzde yeni medya ve dijitalleşme ile tüketicinin ilgi, istek ve ihtiyaçlarına göre bir ürün çerçevesi sunulur (Çakır, 2004, s.175). Kırcova (2008, s.34), geleneksel iletişimde mesaj tek taraflı iletilir ve kullanılan iletişim aracının niteliğine göre cevap süresi birkaç gün veya birkaç hafta bile sürebilir. Bu sebeple internetin iletişimde oluşturduğu kolaylık ile gönderilen mesaj saniyeler içinde alıcıya ulaşır ve bu şekilde iletişimde hız, güncellenebilme ve en önemlisi karşılıklı etkileşim kurulabilir. Doğan (2002, s.41) ise; fiziksel pazar anlayışında bulunan zaman ve mekân kavramlarındaki kısıtlamalara karşı olarak marka ve ürünle daha etkili ve k1sıtlanmadan bir bağ kurması ile hem ulusal hem de uluslararası pazarda çok daha önemli bir yere sahip olunabileceğini belirtir.

Etkileşim reklam sektöründe ne kadar sık kullanılıyor olsa da eksik kalan yönleri ya da dikkat edilmesi gereken tarafları vardır. Özmen'e (2013, s.368) göre bu eksikliklerden bazıları; görsel ve işlevsel olarak kullanıcıya istediğini veremeyen, dönemine uyum sağlayamayan kendini geliştirip sürekli güncellenemeyen web siteleri veya mobil uygulamalar, arama motoru reklamlarında doğru arama kelimesini ürün veya markaya yönlendirememek, kullanıcıya gönderilen rahatsız edecek boyuttaki atılan spam 
mesajlar, sadece reklamın tıklanma sayısını göz önünde bulundurarak ürünü ne kadar incelediği, sayfada ne kadar süre geçirdiği, sonucunda ürünü alıp almamaya karar verdiği gibi bilgilerin yok sayılması, facebook, instagram gibi sosyal medya uygulamalarında topluluk sayfası oluşturarak kaç beğeni kaç takip gibi basit bilgilerle veri elde etmeye çalışmak doğru reklam stratejilerini geliştirmede yetersiz kalır ve bununla orantılı olarak başarı düzeyi de yüksek olmaz. Doğru stratejiler geliştirmek için; arama motorunda doğru kavram ve kelimelerin olması, tüketicinin bu sayede aradığı ürüne daha kolay ulaşması, doğal (organik) optimizasyon ile aranan kelimenin ilk başlarda yer alarak tüketici sayfaya yönlendirilebilmesi, kişiselleştirme özelliğini ile kullanıcı sayfada ne görmek istiyorsa veya ihtiyacı olan ürünler hangisi ise uygulamanın ana sayfasında yer almasını sağlamak, ürünleri fiyat, çeşit veya talebe göre sıralamak ve bu siralamayı kullanıcının da tercihine bırakmak, etkileşimli reklam türlerini en doğru şekilde kullanarak tüketiciye bunu bir deneyim haline getirmesini, eğlenirken, ürün hakkında bilgi sahibi olmasını ve diğer amaçlarını gerçekleştirebilmesi, üretici ve reklamcının hedefini gerçekleştirmesinde önemli adımlardır.

\section{Yöntem}

Bu çalışmada dijital pazarlama stratejisi olarak etkileşimli reklamın etkinliği araştırılmıştır. Bu çerçevede deney olarak tasarlanan çalışmada etkileşimli, pre-roll ve skip pre-roll reklamların etkinlik düzeyleri ölçülerek k1yaslanmıştır. Araştırmanın problem cümlesini; etkileşimli dijital reklamlar, kullanıcıların reklama dikkat düzeyini, reklama yönelik tutumunu, markaya yönelik tutumunu, satın alma niyetini, ürüne yönelik ilgi düzeyini ve bilgi düzeyini farklılaştırıyor mu sorusu oluşturmaktadır.

$\mathrm{Bu}$ araştırmada etkileşimli dijital reklamların etkinliği test edilmiştir. Bu süreçte Deney, Kontrol I. Ve Kontrol II. Grupları oluşturularak deney süreci hazırlanmıştır. Deney sürecinde ürünü satın alan kişilerin reklam ile karşılaşmadan önceki markaya tutumu, ürüne yönelik ön bilgisi, ürün kategorisine yönelik ilgisi ve satın alma niyeti ile reklama maruz kaldıktan sonraki markaya tutumu, ürüne yönelik ön bilgisi, ürün kategorisine yönelik ilgisi ve satın alma niyeti, reklama yönelik tutumu ve reklama yönelik dikkati ölçülerek arasındaki fark belirlenmeye çalışılmıştır. 
Araştırmada deney tasarımı yöntemiyle veri toplama aracı olarak anket kullanılmıştır. Araştırmada 3 farklı reklam türü kullanılarak 3 farklı gruba 7 gün boyunca izletilen reklamların öncesinde ön test ve reklamların bitiminden sonra son test uygulanarak elde edilmiştir.

Ön testte; ürüne yönelik ön bilgi değerlendirmesi, ürün kategorisine yönelik ilgi, markaya yönelik tutum ve satın alma niyeti ölçekleri kullanılmıştır. Ürüne yönelik duygusal ve bilişsel ilgilenim soruları ile reklamı gösterilen Redbull enerji markasına ve enerji içeceklerine yönelik tutum ve bilgilerin ölçülmesi amaçlanmıştır. Araştırmada ürün olarak Redbull kullanılmasının nedeni; araştırma sırasında etkileşimli reklamı bünyesinde kullanan Voscreen uygulamasının etkileşimli reklamlarından kullanılacak ölçeklere en uygunu olmasıdır. Son testte ise aynı şekilde ürüne yönelik ön bilgi değerlendirmesi, ürün kategorisine yönelik ilgi, markaya yönelik tutum ve satın alma niyeti ölçekleri kullanılmıştır. İlaveten reklama yönelik tutum ve reklama dikkat ölçeği de eklenerek anketler oluşturulmuştur. Bu sorular ile Voscreen uygulamasında hazırlanmış olan Playlistte bulunan reklamdaki görsel-yazılı mesajlara ve reklamın tamamına ne ölçüde dikkat ettiği ölçülmeye çalışılmıştır.

Çalışmada veri toplama için Ürün Kategorisine Yönelik Ön Bilgi Ölçeği, Reklama Dikkat Ölçeği, Reklama Yönelik Tutum Ölçeği, Markaya Yönelik Tutum Ölçeği ve Satın Alma Niyeti Ölçeği kullanılmıştır. Ölçeklerin her biri 7'li Likert tarzında ölçeklerdir.

Deney ve kontrol gruplarının benzer özelliklere sahip olması önemlidir. Deney başlangıcında yakın eğitim seviyesine ve kültürel- toplumsal olarak benzer kişilere ulaşılması gerekmektedir. Bu sebeple Süleyman Demirel Üniversitesi İletişim Fakültesi Halkla İlişkiler ve Tanıtım ile Gazetecilik Bölümü aynı sınıf ve yaş grubu öğrencilere ulaşılmıştır. Deney Grubu Gazetecilik II. Öğretim öğrencilerinden oluşurken, Kontrol 1 Grubu Halkla İlişkiler ve Tanıtım bölümü öğrencilerinden oluşur. Kontrol 2 Grubu da Halkla İlişkiler II. Öğretim öğrencilerinden oluşmaktadır.

Araştırmada etkileşimli reklam, pre-roll reklam ve skip pre-roll reklamdan oluşan 3 farklı reklam türü kullanılarak, otuzar kişiden oluşan 90 kişiye, 3 farklı grup şeklinde ayrılarak 7 gün boyunca playlistler izletilmiştir. Grupların 30 kişiden oluşmasının sebebi ise; parametrik bir test yapılabilmesi için yeterli bir sayı olmasıdır. Normal dağılım göstererek, güvenilirlik testlerinde geçerli oranlara ulaşmış olması sebebiyle otuz kişilik 
gruplar uygun görülmüştür. Ardından 7 günlük süreç öncesinde deneye katılacak öğrenciler belirlenmiş ve toplantı düzenlenip ön test uygulanmıştır. 7 günlük sürecin bitiminde öğrencilerle tekrar toplantı düzenlenip son test uygulanmıştır. Gerçekleştirilen ilk toplantıda Voscreen uygulaması tarafından araştırma için oluşturulan 3 ayrı playlist ve 3 ayrı grup olduğu ve 7 gün için ayrı olarak hazırlanan playlist linklerini nasıl kullanacakları, linkler aracılığıyla playlistlere ulaşmak için nasıl kayıt olacakları ve sistem hakkında diğer genel bilgiler verilmiştir. Katılımcılar, her gün 100 videodan oluşan ve her 20 video arasında 1 kez reklam filmi gösterilen playlistlerde günde 5 kez reklama maruz bırakılmıştır. WhatsApp uygulamasından 3 ayrı deney grubu için gruplar oluşturulmuş ve 7 gün süren uygulama süreci içinde online olarak destek sağlanmıştır. Aynı zamanda araştırmaya katılanların günlük çözmeleri gereken 100 video Voscreen tarafindan sistemden kontrol edilmiş, eksik kalanlar tespit edilerek bildirilmiş ve düzenli hale getirilmesi sağlanmıştır.

Voscreen uygulamasının arayüzünde hali hazırda kullanılan etkileşimli reklamlar mevcut olmasına rağmen deney alanı için ayrı bir platform hazırlanmıştır. Bu alanda uygulamada kullanılmakta olan RedBull enerji içeceği reklamı etkileşimli reklamların bulunduğu linke eklenmiştir. Etkileşimli reklamların ölçüldüğü Deney grubuna gösterilen reklamlar; Voscreen uygulamasının mevcut formatı halinde soru-videolar şeklinde hazırlanmış ve kullanıcı ile etkileşimli hale getirilmiştir. Diğer reklam türü olan Pre-roll reklamın yer aldığ 1 Kontrol 1 grubunda ise günlük 100 videodan oluşan listeler için her 20 video-sorudan sonra soru şeklinde olmayan (etkileşimsiz) reklam videosu gelerek sonuna kadar izlenmesi gereklidir. Kontrol 2 grubu için hazırlanan Skip Pre-roll reklamların bulunduğu liste ise günlük 100 videodan oluşan her 20 sorudan sonra gelen geçilebilen pre-roll reklamlar eklenmiştir. Kontrol 1 ve Kontrol 2 grubunda yer alan Pre-roll ve Skip Pre-roll reklamlar, etkileşimli reklamların aksine soru şeklinde olmayan video şeklinde gelerek etkileşimsiz bir reklam modeli olarak kullanıcılara sunulmuştur.

\section{Bulgular}

Çalışmada kullanılan gruplara ait kısaltmalar ve anlamları şu şekildedir: O1: Etkileşimli Reklam: Deney Grubu: Ön test 
- XO2: Etkileşimli Reklam: Deney Grubu: Son test

- O3: Pre- Roll (geçilemeyen): Kontrol 1 Grubu: Ön test

- XO4: Kontrol 1 Grubu: Son test

- O5: Skip Pre- Roll (geçilebilir) - Kontrol 2 Grubu: Öntest

- XO6: Kontrol 2 Grubu: Son test

Deney ve kontrol gruplarının öntest ve sontest güvenilirlik analizlerine ilişkin bulgular Tablo 1'de gösterilmektedir.

Tablo 1. Ölçeklerin Psikometrik Özellikleri

\begin{tabular}{lllllll}
\hline Güvenilirlik Testi & O1 & XO2 & O3 & XO4 & O5 & XO6 \\
\hline Ü.Y. Duygusal İlgilenim & 0,894 & 0,933 & 0,906 & 0,924 & 0,928 & 0,960 \\
Ü.Y. Bilisssel İlgilenim & 0,922 & 0,911 & 0,864 & 0,866 & 0,918 & 0,938 \\
M.Y. Tutum & 0,950 & 0,976 & 0,926 & 0,942 & 0,911 & 0,926 \\
Ü.Y. Bilgi & 0,891 & 0,844 & 0,858 & 0,909 & 0,841 & 0,896 \\
Satın Alma Niyeti & 0,942 & 0,936 & 0,952 & 0,977 & 0,909 & 0,963 \\
Reklama Dikkat & & 0,811 & & 0,712 & & 0,816 \\
Reklama Tutum & & 0,966 & & 0,976 & & 0,946 \\
\hline
\end{tabular}

Testte yer alan her bir ölçek; ürüne yönelik duygusal ilgilenim, ürüne yönelik bilişsel ilgilenim, markaya yönelik tutum, ürüne yönelik bilgi, satın alma niyeti, reklama dikkat, reklama tutum alt ölçeklerinden oluşmaktadır. Testin güvenilirlik analizinde, Cronbah's Alpha verilerinin 0,7'nin üzerinde olması güvenilir olduğu sonucuna ulaşmada yeterlidir.

Deney 1 (O1- XO2) grubuna katılan 30 katılımcıdan \%63,3'ü kadın, \%36,7'i erkektir. Deney uygulanmadan önceki O1 verilerine göre; ürünü tüketenler \%70 iken ürünü tüketmeyenler \%30'dur. Kontrol I (O3- XO4) grubuna katılan 30 katılımcıdan \%66,7'si kadın, \%33,3'ü erkektir. Deney uygulanmadan önceki O3 verilerine göre; ürünü tüketenler \%80 iken ürünü tüketmeyenler \%20'dir. Kontrol II (O5- XO6) grubuna katılan 30 katılımcıdan \%53,3'si kadın, \%46,7'si erkektir. Deney uygulanmadan önceki O3 verilerine göre; ürünü tüketenler $\% 83,3$ iken ürünü tüketmeyenler $\% 16,7^{\prime}$ dir.

Katılımcıların alt ölçeklerden aldıkları puanlara ilişkin veriler Tablo 2'de gösterilmiştir. 
Tablo 2. Alt Ölçeklerin Ortalama ve Standart Sapmalarn

\begin{tabular}{|c|c|c|c|c|c|c|c|c|c|c|c|c|c|c|c|}
\hline \multirow{2}{*}{$\begin{array}{l}\text { Betimsel } \\
\text { İstatistik } \\
\text { Değerleri } \\
\end{array}$} & \multicolumn{2}{|c|}{ O1 } & \multicolumn{2}{|c|}{ XO2 } & \multicolumn{3}{|c|}{ O3 } & \multicolumn{2}{|c|}{ XO4 } & \multicolumn{3}{|c|}{ O5 } & \multicolumn{2}{|c|}{ XO6 } & \multirow[b]{2}{*}{ 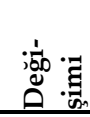 } \\
\hline & $\bar{x}$ & $S$ & $\bar{x}$ & $S$ & 递 & & $S$ & $\bar{x}$ & $S$ & 沕 & & $S$ & $\bar{x}$ & $S$ & \\
\hline $\begin{array}{l}\ddot{U} . Y . \\
\text { Duygusal } \\
\text { İlgilenim }\end{array}$ & 3,1 & 1,4 & 3,3 & 1,4 & 0,23 & 3,8 & 1,4 & 3,7 & 1,4 & $-0,08$ & 3,7 & 1,5 & 3,9 & 1,6 & 0,18 \\
\hline 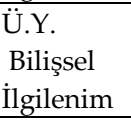 & 2,9 & 1,4 & 2,9 & 1,4 & 0,05 & 3,2 & 1,4 & 3,2 & 1,4 & 0,03 & 3,5 & 1,6 & 4 & 1,6 & 0,44 \\
\hline $\begin{array}{l}\text { M.Y. } \\
\text { Tutum }\end{array}$ & 3,6 & 61,4 & 3,8 & 1,7 & 0,23 & 4,5 & 1,4 & 4,3 & 1,5 & $-0,21$ & 4,5 & 1,4 & 4,6 & 1,5 & 0,11 \\
\hline $\begin{array}{l}\text { Ü.Y. } \\
\text { Bilgi }\end{array}$ & 3 & 1,5 & 2,4 & 1 & $-0,58$ & 2,2 & 1,1 & 2,4 & 1,4 & 0,23 & 2,3 & 1 & 2,8 & 1,3 & 0,47 \\
\hline $\begin{array}{l}\text { Satın } \\
\text { Alma } \\
\text { Niyeti }\end{array}$ & 3,6 & 2,2 & 3,8 & 2,2 & 0,23 & 4,6 & 2 & 4,6 & 2 & 0 & 4,7 & 1,8 & 4,5 & 2 & $-0,2$ \\
\hline $\begin{array}{l}\text { Reklama } \\
\text { Dikkat }\end{array}$ & & & 5,6 & 1,3 & & & & 5,4 & 1,1 & & & & 4,6 & 1,5 & \\
\hline $\begin{array}{l}\text { Reklama } \\
\text { Tutum }\end{array}$ & & & 4,1 & 1,7 & & & & 4 & 1,6 & & & & 4,4 & 1,2 & \\
\hline $\begin{array}{l}\text { Tüm } \\
\text { Ölçek }\end{array}$ & 3,2 & 1,3 & 3,7 & 1,2 & 0,54 & 3,6 & 1,2 & 3,9 & 1,2 & 0,36 & 3,7 & 1,1 & 4,1 & 1,1 & 0,46 \\
\hline
\end{tabular}

Tüm ölçeğe baktığımızda deney grubunda 3,19'dan 3,73'e yükselerek $+0,58$, Kontrol 1 grubunda 3,56' dan 3,92'e yükselerek +0,36, Kontrol 2 grubunda ise 3,67' den 4,13 yükselen 0,46 artış görülmektedir. Ürün grubuna dair reklama maruz kalma söz konusu olduğu için grupların tamamında artış olmuştur. Fakat üç grup arasında en az artışın Kontrol I grubunda olması zoraki olarak reklama maruz kalma ve herhangi bir etkileşim olmadan reklamı sonuna kadar izlemesi gerektiği söylenebilir. En yüksek artış oranı etkileşimli reklamın uygulandığ 1 deney grubunda sağlanmıştır ve etkileşimli reklamların pre-roll ve skip pre-roll reklama göre daha etkin bir reklam türü olduğu bulunmuştur.

Katılımcıların ön test ve son testlerine ait puanları arasındaki farklara ilişkin bulgular Tablo 3'te verilmiştir. 
Tablo 3. Wilcoxon Test Sonuçları

\begin{tabular}{|c|c|c|c|c|c|c|}
\hline $\begin{array}{l}\text { Wilcoxon } \\
\text { İşaretlenmiş } \\
\text { Siralar Testi }\end{array}$ & $\begin{array}{l}\text { Ü.Y. } \\
\text { Duygusal } \\
\text { İlgilenim }\end{array}$ & $\begin{array}{l}\text { Ü.Y. } \\
\text { Bilişsel } \\
\text { İlgilenim }\end{array}$ & $\begin{array}{l}\text { M.Y } \\
\text { Tutum }\end{array}$ & $\begin{array}{l}\text { Ü.Y. } \\
\text { Bilgi }\end{array}$ & $\begin{array}{l}\text { Satın } \\
\text { Alma } \\
\text { Niyeti }\end{array}$ & $\begin{array}{l}\text { Tüm } \\
\text { Ölçek }\end{array}$ \\
\hline $\mathrm{O} 1$ & $-1,924^{b}$ &,$- 890^{b}$ & $-1,737^{b}$ & $-1,869^{c}$ &,$- 693^{b}$ & $-3,054^{b}$ \\
\hline $\mathbf{p}$ & 0,054 & 0,373 & 0,082 & 0,062 & 0,488 & 0,002 \\
\hline
\end{tabular}

a. Wilcoxon Signed Ranks Test

b. Based on negative ranks

c. Based on posiitive ranks

Farkın Etki Büyüklüğü: 0,557

$\begin{array}{llllllll}\text { O3 } & \mathbf{z} & -, 703^{\mathrm{b}} & -, 098^{\mathrm{c}} & -, 985^{\mathrm{b}} & -1,377^{\mathrm{c}} & , 000^{\mathrm{d}} & -2,828^{\mathrm{c}} \\ & \mathbf{p} & 0,482 & 0,922 & 0,325 & 0,168 & 1,000 & 0,005\end{array}$

a. Wilcoxon Signed Ranks Test

b. Based on positive ranks

c. Based on negative ranks

d. the sum of negative ranks equals the sum of positive ranks

Farkın Etki Büyüklügü: 0,516

$\begin{array}{llllllll}\text { O5 } & \mathbf{z} & -1,133^{\mathrm{b}} & -2,322^{\mathrm{b}} & -, 544^{\mathrm{b}} & -2,544^{\mathrm{b}} & -, 808^{\mathrm{c}} & -3,908^{\mathrm{b}} \\ & \mathbf{p} & 0,257 & 0,020 & 0,586 & 0,011 & 0,419 & 0,000\end{array}$

a. Wilcoxon Signed Ranks Test

b. Based on negative ranks

c. Based on positive ranks

Farkın Etki Büyüklüğü: 0,713

Tablo 3'e bakıldığında üç grupta da öntest ve sontest sonuçları arasinda anlamlı bir farklılık görülmektedir. Farkın etki büyüklüğü genel olarak 1'in üzerinde çok büyük olarak ifade edilirken, 0,8 büyük, 0,5 orta, 0,2 az olarak değerlendirilmektedir. Farkın etki büyüklügü hesaplanırken $t$ değerinin, örneklem mevcudunun kareköküne oranı etki büyüklügünü vermektedir (Can, 2014, s.112).Uygulanan ölçeğin deney grubunda ön test ile son test arasındaki farkın anlamlılığını ölçtüğümüz Wilcoxon işaretlenmiş sıralar testinde bu farkın 0,002 düzeyinde olduğu gözlemlenmiştir. Bu durumda deney grubunda uygulanan etkileşimli reklam örneğinin istatistiki olarak anlamlı derecede diğer reklam türlerinden orta düzeyde daha etkin olduğu görülmüştür. Etki büyüklüğü en fazla olan grubun Kontrol 2 grubu olduğu görülmektedir. Bu noktada geçilemeyen reklamı izlemek zorunda kalan katılımcıların reklamı geçebilen ve reklama dâhil olan katılımcılardan daha fazla değişim yaşadı̆̆ı gözlenmiştir. 


\section{Tartışma ve Sonuç}

Teknolojinin gelişimi çoğu disiplinde olduğu gibi iletişim alanında da önemli değişimleri beraberinde getirmiştir. Kitle iletişim araçlarının dijitalleşmesi, insan yaşamının önemli olgularından olan kültürü de etkisi altına almıştır. Kültür, toplumun duygusal ve maddesel ihtiyaçlarına etki ederek; sanat, sosyoloji, psikoloji, bilim, teknoloji, iletişim, siyaset, ekonomi, dil, tarih ve daha pek çok disipline yansımaktadır. Bu olgulardan olan iletişim ise insanlık tarihinin başından beri var olarak bilim ve teknolojinin gelişimiyle sürekli yenilenmiş ve farklılaşmıştır. Dijitalleşme ile yaşanan bu değişimler günlük hayattaki düşünce, davranış, tutum ve ilişkilerimize yansıyarak; "dijital yerli”, "dijital kuşak”, "doğuştan dijital”, "ağ toplumu" gibi ifadeleri ortaya çıkarmıştır. Dijitalleşmenin hayatımızdaki yeri kişiler üzerindeki kavramsallaşmadan da anlaşılacağı üzere oldukça önemlidir. Böylece birçok disiplinde olduğu gibi reklam sektöründe de dijitalleşme gerçekleşerek yeni kavramları beraberinde getirmiştir.

Teknolojik gelişmeler ile meydana gelen kültürel değişimler ve görsel kültür, toplumsal algı değerlerinde önemli farklılıklar getirmiştir. Bu farklilıklar ise hem kişiye hem de toplumsal alana etkide bulunarak görsellik ile ortaya çıkan yeni bir kültür oluşturmuştur. Hall'un, (1998: 47) “dijital görüntünün egemenliği" olarak açıkladığı görüntünün, artık dilin eksik kaldığ1 ve sonucunda iletişimin zorlaştığı süreci atlayarak görsellik üzerinden kurulan bir küresel kültürden söz etmektedir. Küresel kültürün ortaya çıkması ve dijital görsel kültürün hâkim olmasıyla dil faktörü artık önemini yitirmektedir. Dünya üzerinde farklı dili kullanan, farklı kültürlere ait olan birçok toplum iletişim kurabilir, görseller yolu ile gündem hakkında bilgi sahibi olarak, küresel gelişmeleri takip edebilir ve farklı toplumlarda araştırma yapabilir. Bu bağlamda görseller dijital çağda oldukça önemli bir yere sahiptir.

Görselliğin yanı sıra ses, metin, video gibi içeriklerin de kullanılabildiği internet ile kullanıcı kategorisi için en uygun reklam türü seçilmeye çalışılarak en etkili sonuçların alınması hedeflenir. Bu bağlamda günümüzde sık olarak kullanılan ve çalışmada incelenen; banner, pop-up, rich media, video, arama motoru, SEO, SEM, E-posta, sosyal medya, facebook, twitter, instagram, vlog, blog, web site, viral, advergaming, native (doğal) vb. reklam türleri mevcuttur. 
Dijital reklam türleri arasında etkileşimli reklamın etkinliğinin ölçüldüğü çalışmada etkileşimli reklam, pre-roll ve skip pre- roll reklamlar kullanılarak araştırma gerçekleştirilmiştir. Yapılan deney uygulaması sonucunda etkileşimli reklamın diğer dijital reklam türlerine göre katılımcıların olumlu görüşlerinin, ürüne yönelik duygusal ve bilişsel ilgileniminin, markaya yönelik tutumu ve satın salma niyetinin olumlu yönde arttığ söylenebilir. Ek olarak etkileşimli reklamın reklama dikkati diğer dijital reklam türlerine göre daha fazla sağlayabildiğini söyleyebiliriz. Bu durumda dijital pazarlama stratejisi olarak dijital etkileşimli reklamların diğer reklamlara göre daha etkili olduğunu söylemek mümkündür.

Çalışma sonucunda etkileşimli reklamların kullanıcı ile etkileşim halinde kalarak devamlılık sağlaması reklamın etkinliğini artırmaya yönelik bir öneri olarak sunulabilir. Öte yandan kullanıcının reklam sürecine tamamen dâhil edilmesi ile birlikte reklam içerik ve tasarımının belirli aralıklarda yenilenmesi de bir öneridir.

Reklam tasarımının dikkat çekici, özgün bir tasarıma sahip olması ve araçsal kullanımın dâhil edilmesi de reklam etkinliğini artırmada önemli koşullardır. Bununla birlikte çağımızın getirdiği tüm teknolojik yenilikleri yakından takip ederek ve hatta ön görülen gelişmeleri içeren reklam çalışmaları tasarlanmalıdır. Örneğin; reklamda artırılmış gerçeklik kullanımı, bu gerçekliğe tüketici dâhil olacağı ve etkileşim halinde olacağından ürüne yönelik tutumu ve satın alma niyeti olumlu yönde değişebilir. 


\title{
EXTENDED ABSTRACT
}

\section{Effectiveness of Interactive Advertising As A Digital Marketing Strategy: An Experimental Study}

\author{
Makbule Büşra Çetinkaya - Rukiye Çelik \\ $*$ \\ Suleyman Demirel University
}

Today, the widespread use of computers and smart phones has enabled the frequency of internet advertisements and often preferred by advertisers or institutions. Internet advertising is used as an advanced form of traditional advertising practices. It is thought that the internet cannot be seen as a new application in advertising media and that traditional advertising media cannot go far beyond it and it does not carry significant differences except for technology and different methods. It is a form of advertising that is connected to user control because the ads applied on the internet are a process that works by attracting the attention of the user and asking for information about them. According to Cappo (2005, p.195), the versatility of the internet network makes it different from other media and superior to other media.

This communication environment, which is easily accessible for traditional media, has become an important tool for traditional advertising to reach the user. The internet has also transformed traditional advertising into a different format and interactive advertising has developed in this way. Digital ads; internet, telephone, computer etc. it reaches the user and consequently interacts with the user and the ad. The interaction with concurrency occurs in two-way communication via the internet, and as a result, the user becomes open to communication against advertisement (Günay, 1999, p.47).

In this study, the effectiveness of interactive advertising as a digital marketing strategy was investigated. In this study, the effectiveness levels of interactive, pre-roll and skip pre-roll ads were measured and compared. The problem sentence of the research; interactive digital ads, users ' ad attention level, ad-oriented attitude, brand-oriented attitude, intention 
to buy, product-oriented interest level and information level are different.In this study, the experimental design method was used as a data collection tool.

In the research, three different types of advertisement types were obtained by using the pre-test and the final Test after the end of the advertisement before the advertisement that was followed for 7 days in 3 different groups.

In this study, interactive advertising, pre-roll and skip pre-roll ads were investigated. As a result of the experiment conducted, it can be said that the positive views of the participants according to the other digital advertising types of Interactive Advertising increased positively by the emotional and cognitive interest of the product, the attitude towards the brand and the intention to sell. In addition, we can say that Interactive Advertising can provide more advertising attention than other types of Digital Advertising. In this case, as a digital marketing strategy, it is possible to say that digital interactive ads are more effective than other ads.

As a result of the study, interactive ads interact with the user to ensure continuity may be presented as a recommendation to increase the effectiveness of the ad. On the other hand, it is also a recommendation that the advertising content and Design be renewed at certain intervals with the inclusion of the user in the advertising process.

Advertising design has a remarkable original design and the inclusion of the use of tools are important conditions in increasing the effectiveness of advertising. However, all technological innovations brought by our age should be closely followed and even ad studies should be designed to include the developments seen. For example, the use of augmented reality in advertising may change positively, as this reality will include the consumer and will interact with the product.

\section{Kaynakça / References}

Aksoy, R. (2009). Internet ortamında pazarlama. Ankara: Seçkin Yayıncilık. Aktaş, H. (2010). İnternet reklam türlerinde uygulayıcılardan kaynaklanan sorunlar ve bir sınıflandırma önerisi. Selçuk Üniversitesi İletişim Fakültesi Akademik Dergisi, 3, 147-166. 
Alan, K. A., Kabadayı, E. T. ve Erişke, T. (2018). İletişimin yeni yüzü: dijital pazarlama ve sosyal medya pazarlaması. Elektronik Sosyal Bilimler Dergisi, 17, 493-504.

Dijital pazarlama. (t.y.) Business dictionary. 08.02.2019 tarihinde http://www.businessdictionary.com/definition/digital-marketing.html adresinden erişilmiştir.

Can, A. (2014). SPSS ile bilimsel araştırma sürecinde nicel veri analizi. Ankara: Pegem Akademi.

Çakır, V. (2004). Yeni iletişim teknolojilerinin reklam üzerine etkileri. Selçuk Üniversitesi İletişim Fakültesi. 2, 168-181.

Çelik, N. (2016). Reklamcılıkta dijital dönüşüm ve uygulamaları üzerine bir inceleme. Doktora Tezi, İstanbul Üniversitesi Sosyal Bilimler Enstitüsü, İstanbul.

Doğan, H. (2002). Karşı etkileşimli pazarlama. Isparta: Fakülte Kitabevi.

Erdem, M. N. (2014). Tüketime dayıl bilinç endüstrisi ve reklam bağlamında bir dijital reklam okuryazarlığı eğitim modeli önerisi. Doktora Tezi, Kocaeli Üniversitesi Sosyal Bilimler Enstitüsü, Kocaeli.

Güney, Z. (2006). Etkileşimli reklam planlama ve yaratım süreci. Yüksek Lisans Tezi, Marmara Üniversitesi Sosyal Bilimler Enstitüsü, İstanbul.

Hartman, A., Sifonis, J. ve Kador, J. (2002). A stratejileri. İstanbul: Literatür Yayıncılık.

İnce, M. (1999). Elektronik ticaret: Gelişme yolundaki ülkeler için imkanlar ve politikalar. İktisadi Sektörler ve Koordinasyon Genel Müdürlüğü Hukuki Tedbir-ler ve Kurumsal Düzenlemeler Dairesi Başkanlığı, Ankara.

Kurcova, İ. (2008). Internette pazarlama. İstanbul: Beta Yayıncilık.

Kotler, P., Kartajaya, H. ve Setiawan, I. (2010). Pazarlama 3.0. (K.Dündar Çev.) İstanbul: Optimist Yayım Dağıtım.

Köse, N. ve Yengin, D. (2018). Dijital pazarlamadan fijital pazarlamaya geçişe örnek olarak artırılmış gerçeklik ve sanal gerçeklik uygulamalarının pazarlama üzerindeki katkılarının incelenmesi. İstanbul Aydın Üniversitesi Dergisi (İÄ̈D). 1, 77-110.

Önal, İ. ve Bendaş, K. (2017). Sinoptik çağda gözetimin morfolojisi: takip edilmek ve internet reklamcilığı. T.C. Kültür ve Turizm Bakanlığı GENÇDES, ANASAY. 2, 109-117. 
Özkaya, B. (2010). Reklam aracı olarak Advergaming. Marmara Üniversitesi I.I.I.B.F. Dergisi, 2, 455-748.

Özmen, Ş. (2013). A $\breve{g}$ ekonomisinde yeni ticaret yolu: E-ticaret. İstanbul: İstanbul Bilgi Üniversitesi Yayınları.

Peltekoğlu, F. B. (2016). Halkla ilişkiler nedir? İstanbul: Beta Yayıncılık.

Penpece, D. (2013). Dijital içerik pazarlaması. Adana: Karahan Kitabevi.

Şahin, S. (2018). 21. Yüzyıl teknolojileriyle etkileşim: Sanat - Reklam - Birey. Journal of Arts. 1, 23-30.

Tosun, N. B. (2004). Kullanılan teknikler açısından internet reklamları. Selçuk İletişim Dergisi. 2, 159- 167.

Varnalı, K. (2013). Dijital Tutulma. İstanbul: MediaCat Kitapları.

Vural, İ. ve Öz, M. (2007). Bir reklam mecrası olarak internet. Sosyal Bilimler Enstitüsü Dergisi. 23, 221- 240.

Yengin, D. (2012). Yeni medyaya eleştirel bir bakış. (D. Yengin, Ed.) Yeni medya ve... içinde (s.123-134) İstanbul: Anahtar Kitapları Yayınevi.

Yılmaz, R. (2017). Türkiye'de reklam anlatısının dijital çağdaki yapısal dönüşümü. Ondokuz Mayıs Üniversitesi İletişim Fakültesi I. Uluslararası İletişimde Yeni Yönelimler Konferansı. Bildiriler Kitabı içinde (s.260267), 4-5 May1s 2017, Samsun

Yüksektepe, M. ve Haşığlu, S. B. (2017). Dijital dünya ile birlikte değişim gösteren bir kavram: Reklam. IBANESS Congress Series, 270- 276.

\section{Kaynakça Bilgisi / Citation Information}

Çetinkaya, M. B. ve Çelik, R. (2019). Bir dijital pazarlama stratejisi olarak etkileşimli reklamların etkinliği: Deneysel bir çalışma. OPUSUluslararası Toplum Araştırmaları Dergisi, 12(18. UİK Özel Sayısı), 486-506. DOI: 10.26466/opus.583849. 